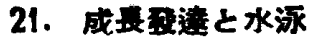

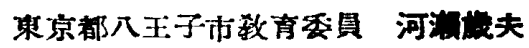

1. いつ頃から涾けるようになるか カーブは小祭校三年において 急上䄯する

2. どえな棣さ方が最初に行われるか 平泳さ一横泳き

3. 性別による涾丸力の異い 女子の平泳ぎ・横泳ぎ，男子の犬かき・ クロール

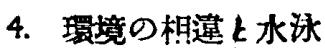
(イ)非常に患まれた所の者の泳きはじ夕る

第2 日 11 月 24 日（土）

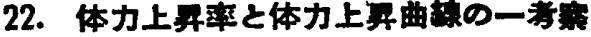

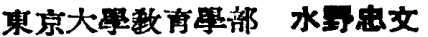

(1) 体力上较は体力テストの結果考察の成の 一方法である。通常この種のテストの結果は $N$ ，

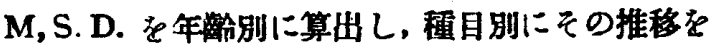
みて㑯问を判断するのであるが，硬目を異にし， 測定の單位を巽に一るを，その間の比恔は $\mathrm{N}, \mathrm{M}$, S. D. ボけでは簡單に鹪し得さる不便がある。走 力子跳力の上年倾向の比較の如きがその例であ る.そこでニの不便る除く需に上界の数量的差を 此整の形に變更のることが考えられる，体力上㫒 奉はかろる目的の鹪に使用らる一方式である。

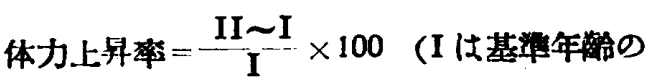

M,IIは上昇したそれぞれの年羭の M)

(2) この㖃力上昇率を使用与ることによつて各

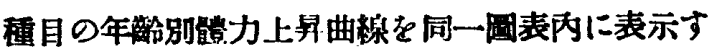
るここが出來. 從つて体力上影㑯向の把揘が可能

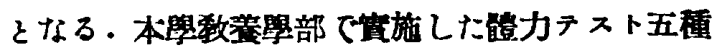
目の結果をこの方法で整理した結果，骂生の休力 上昇の傾向が主として下肢を使用する運動ては少 く，上肢運動で大きいことを把揘することが出來 た。

\section{3. 通虾运手の偣について}

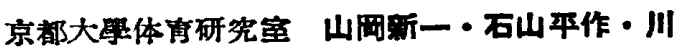

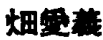

各部運動の選手は强い体力と高い健康度をるつ
涾げる者の数。㐰やう惠まれたるころの 者の泳きはしめと泳げる者の数，代割合 僖まれない所の者の泳ざはじると泳げる 者の数

5. 水に對する關心はいつ比が最る强いか

(1) 水にあこがれる年䧗

(可) 水に關心のない者の理由

6. 當研究はベーパー・テストによる。地域㓢 に悬校党抽出して行う．学考までに中等生 の調查るして考察に加えた．水泳のカリキ ニラム作慗と水泳指導に窟考になれば幸で ある.

午後之部（午後 1 時 $５$ 時）

ているように考えられているが，私達仕本校學生 の各部選手について体力・健康度，特に結核に閶

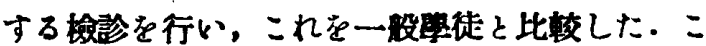
れによれは過去にかいて運動選手であつたか，ま たは現在におけて選手であるるのは，一般篹徒に 比し，かえつて結核の惟患率が高い事を知つた。 郎ち運動榞を有するるのは8.6\%，そうでないるの は 4.2\%の結核率を示している。

各部の運動種別に体格・身体・機能などをしら べてみてる，それらの間にそれでれ相異がある。 私達は，運動選手はいうまでるなく，そうでない ものb趾康度を少くをる3 段階に分けて建康管理 を㦑に行うべきこをを提唱し，そのまえに健康度。 の分類を行つたから、ここに裂表する。

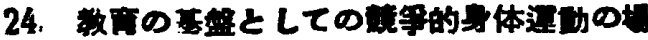

\section{静岡大等 石樌武素}

競争的身体運動の場——試会の場の特異な粠造 乃至機能数育の基盤飞言う見地から取り上け解 明を試みたるのである。

25. 体市の㑑人道栍に国する研究（算 2 報）

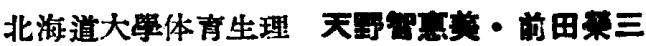
- 多田武夫

1. 前回に於ては吾\&の考案した交流计心電訐

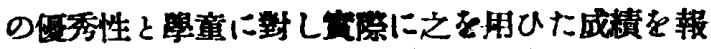
告したが，今回は更に農村の中學生 100 名に附き 